\title{
Effects of bioactive peptides isoleucine-proline-proline (IPP), valine-proline- proline (VPP) and leucine-lysine-proline (LKP) on gene expression of osteoblasts differentiated from human mesenchymal stem cells
}

\author{
Minna M. Huttunen*†, Minna Pekkinen†, Mikael E. B. Ahlström and Christel J. E. Lamberg-Allardt \\ Calcium Research Unit, Department of Applied Chemistry and Microbiology, University of Helsinki, Helsinki, Finland \\ (Received 19 December 2006 - Revised 14 March 2007 - Accepted 20 March 2007)
}

Food-derived bioactive peptides are reported to express a variety of functions in vivo. We studied the in vitro effect of three bioactive tripeptides, isoleucine-proline-proline (IPP), valine-proline-proline (VPP) and leucine-lysine-proline (LKP), on osteoblast proliferation and gene expression. We used UMR-106 osteosarcoma cells, human marrow-derived mesenchymal stem cells (hMSC) and osteoblasts differentiated from hMSC. Treatment with $50 \mu \mathrm{M}$-IPP increased UMR-106 cell and hMSC proliferation. The gene expression of hMSC-differentiated osteoblasts was analysed by the microarray method. Microarray analysis revealed that IPP up-regulated 270 genes and down-regulated 100 genes. VPP and LKP, by contrast, had a very modest influence on osteoblast gene expression. Real-time PCR confirmed that IPP up-regulated PTHrP, BMP-5 and CREB-5 and down-regulated VDR and caspase-8. IPP possesses potential to increase osteoblast proliferation, differentiation and signalling. Agents that increase the number and function of osteoblasts could improve bone mass and structure, and decrease fracture risk.

IPP: Osteoblast proliferation: Dietary protein: Bioactive peptide

Protein accounts for one-third of bone mass, making bone one of the most protein-dense tissues of the body. Many epidemiological studies report high dietary protein intake to have a positive association with bone mineral mass ${ }^{1-4}$ and fracture repair $^{5-7}$. Dietary protein plays an important role in bone strength $^{4,8}$ as it is essential for bone turnover and matrix formation $^{8,9}$. Moreover, dietary protein increases intestinal calcium absorption ${ }^{10}$, enhances insulin-like growth factor-I production and action ${ }^{11}$, and serves as a source of bioactive compound formation.

Bioactive peptides can be present as such in dietary protein or incorporated in the primary sequence of proteins. Active peptides are released when proteins are broken down in the gastrointestinal tract by proteolytic enzymes and in the bacterial fermentation processes. Active peptides can be formed from protein of animal and plant origin ${ }^{12}$. Good candidate proteins for peptide formation come from eggs, meat, fish, soya and wheat, but by far the most from milk-based products ${ }^{13}$. Naturally occurring bioactive peptides are found in traditional foods such as ripened cheese and lactic acid fermented sour milk. During microbial fermentation bioactive peptides isoleucine-proline-proline (IPP) and valine-proline-proline (VPP) are formed from milk caseins. Leucine-lysine-proline (LKP), another active peptide, is found in traditional Japanese fish meal containing processed dried bonito ${ }^{14}$. The commercially available functional foods containing bioactive peptides include soft drinks (caseinophosphopeptide), milk drink (VPP, IPP), soup (LKP) and sour milk (VPP, IPP) ${ }^{13}$. Bioactive peptides are also used in non-food matrices for health effects, e.g. toothpaste, mouth rinse and chewing gum ${ }^{13}$. Bioactive peptides have a wide range of activities. Some peptides express activity in the intestine ${ }^{15}$, others after absorption ${ }^{16}$. Their actions vary from anticariogenic and antimicrobial functions to opioid-like neuronal effects and angiotensin-converting enzyme inhibitory effects ${ }^{17-19}$. Peptides remaining functional after absorption are typically two to five amino acids in length and have a proline residue in their C-terminus $^{20}$. This structure is common among food-derived tripeptides such as IPP, VPP and LKP.

The in vivo effects of IPP and VPP on calcium and bone metabolism have been studied in rats and man. Lactobacillus helveticus-fermented milk containing IPP and VPP increased bone mineral density in growing rats $^{21}$ and acute calcium absorption in postmenopausal women ${ }^{22}$. These results suggest bioactive peptides can aid bone mass development and maintenance.

The aim of the present in vitro study was to investigate the effects of IPP, VPP and LKP on osteoblast proliferation and to clarify their function at the gene level. The results contribute to a better understanding of how bioactive peptides affect

Abbreviations: BMP, bone morphogenetic protein; CREB, cAMP response element binding protein; hMSC, human mesenchymal stem cells; IPP, isoleucine-prolineproline; LKP, leucine-lysine-proline; PTH, parathyroid hormone; qRT-PCR, quantitative real-time PCR; VDR, vitamin D receptor; VPP, valine-proline-proline.

*Corresponding author: Dr Minna M. Huttunen, P.O. Box 66, 00014 University of Helsinki, Helsinki, Finland, fax +358 9 191 58269, email minna.huttunen@helsinki.fi

$\dagger$ These authors contributed equally to the study. 
osteoblasts and human mesenchymal stem cells and shed light on the mechanisms by which dietary protein supports bone health at the cellular level.

\section{Materials and methods}

\section{Cell culture}

UMR-106 rat osteosarcoma cells (American Type Culture Collection) were used for preliminary screening of suitable peptide concentration and treatment time. UMR-106 cells were used because they grow fast and share a number of phenotypic properties with mature osteoblasts ${ }^{23}$. UMR-106 were grown in Dulbecco's modified Eagle's medium, supplemented with $10 \%$ fetal calf cerum, $50 \mathrm{IU}$ penicillin and $50 \mu \mathrm{g} / \mathrm{ml}$ streptomycin at $37^{\circ} \mathrm{C}$ in a humified atmosphere with $5 \%$ $\mathrm{CO}_{2}$ on ninety-six-well plates. The cells were seeded at $1 \times 10^{4}$ cells $/ \mathrm{cm}^{2}$, cultured for $24 \mathrm{~h}$ and thereafter the medium was changed to fresh medium containing various concentrations of IPP, VPP or LKP.

A cell line prepared from tumour tissue may not correctly reflect osteogenic changes in normal human mesenchymal lineages, hence we used human mesenchymal stem cells (hMSC; Poietics, Cambrex Bio Science, Walkersville, MD, USA) purified from bone marrow and osteoblasts differentiated from them. The hMSC cells were seeded at 3100 cells $/ \mathrm{cm}^{2}$ and cultured in Poietics mesenchymal stem cell growth medium with mesenchymal cell growth supplements (Cambrex Bio Science) at $37^{\circ} \mathrm{C}$ in a humified atmosphere with $5 \% \mathrm{CO}_{2}$ on ninety-six-well plates or $10 \mathrm{ml}$ plastic dishes. Differentiation of the hMSC into osteoblasts was induced when the cultures were approximately $50 \%$ confluent. The medium was then substituted with either a fresh growth medium ( $\alpha$-modified Eagle's medium, $10 \%$ fetal bovine serum, $100 \mathrm{U} / \mathrm{ml}$ penicillin and $100 \mathrm{U} / \mathrm{ml}$ streptomycin) or a differentiation medium ( $\alpha$-modified Eagle's medium, $10 \%$ fetal bovine serum, $10^{-8} \mathrm{M}$-dexamethasone, $50 \mu \mathrm{g} / \mathrm{ml} \mathrm{L}$ ascorbic acid and $10 \mathrm{~mm}-\beta$-glyserophosphate (GP), $100 \mathrm{U} / \mathrm{ml}$ penicillin and $100 \mathrm{U} / \mathrm{ml}$ streptomycin). After $12-14 \mathrm{~d}$ of differentiation osteoblastic phenotype was confirmed by the amplification of osteocalcin with quantitative real-time PCR (qRT-PCR; primers in Table 1), by alkaline phosphatase staining (Sigma Histological Alkaline Phosphatase Kit No. 86; Sigma, St Louis, MO, USA) and by assessing mineralization with Alizarin Red S staining ${ }^{24}$. There was no visible alkaline phosphatase staining or mineralization in the undifferentiated cells (Fig. 1). Osteoblastic phenotype was confirmed before each experiment.

Isoleucine-proline-proline, valine-proline-proline and leucinelysine-proline tripeptides

The peptides were synthesized by 9-fluorenylmethyloxycarbonyl chemistry and purified by HPLC reverse-phase columns. Peptides were synthesized in the Core Facility for Synthetic Peptides, at the Division of Biochemistry, Department of Biological and Environmental Sciences, University of Helsinki, Finland. Peptides were dissolved in sterile water prior to administration.

\section{Proliferation assay}

A proliferation experiment was carried out with 5, 50 and $500 \mu \mathrm{M}$-peptide concentrations and with treatment times of 6,24 and $48 \mathrm{~h}$. DNA synthesis activity was assessed by a Cell Proliferation ELISA kit (Roche Diagnostics GmbH, Mannheim, Germany). The 5-bromo-2'-deoxyuridine (BrdU) binds to the newly synthesized cellular DNA. The 5-bromo-2'-deoxyuridine incorporation was measured with a spectroscopic plate reader at $450 \mathrm{~nm}$ (Multiskan Ex; Thermo Labsystems, Helsinki, Finland). The assay was performed twice on eight replicate observations per experiment.

\section{Total RNA isolation}

Total RNA from the hMSC-differentiated osteoblasts was extracted from two separate experiments using RNeasy Protect mini kit (Qiagen GmgH, Hilden, Germany). The RNA concentration was measured at $260 \mathrm{~nm}$ by a spectrophotometer (SmartSpec $^{\text {TM } 3000 ; ~ B i o-R a d, ~ H e r c u l e s, ~ C A, ~ U S A) . ~ I n t e g r i t y ~}$ of RNA was confirmed by formaldehyde agarose gel $(1.2 \%)$ electrophoresis.

Table 1. Primer sequences for quantitative real-time $\mathrm{PCR}^{\star}$

\begin{tabular}{|c|c|c|c|}
\hline Primer & Sequence & Product size (bp) & Reference no. \\
\hline$\beta$-Actin & $\begin{array}{l}\text { Forward: AGGCCAACCGCGAGAAGATGACC } \\
\text { Reverse: GAAGTCCAGGGCGACGTAGCAC }\end{array}$ & 350 & 43 \\
\hline BMP-2 & $\begin{array}{l}\text { Forward: GGAGAAGGAGGAGGCAAG } \\
\text { Reverse: GACACGTCCATTGAAAGAGC }\end{array}$ & 100 & 44 \\
\hline BMP-5 & $\begin{array}{l}\text { Forward: AAGAGGACAAGAAGGACTAAAAATAT } \\
\text { Reverse: GTAGAGATCCAGCATAAAGAGAGGT }\end{array}$ & 303 & 43 \\
\hline Caspase-8 & $\begin{array}{l}\text { Forward: AGGAGGAGATGGAAAGGGAACTT } \\
\text { Reverse: ACCTCAATTCTGATCTGCTCACTTCT }\end{array}$ & 108 & 45 \\
\hline CREB-5 & $\begin{array}{l}\text { Forward: GCTTTGGTGCTTTTCTCCAG } \\
\text { Reverse: GGTGACACCACAGCACAAAC }\end{array}$ & 245 & - \\
\hline $\mathrm{OCN}$ & $\begin{array}{l}\text { Forward: ATGAGAGCCCTCACACTCCTCG } \\
\text { Reverse: GTCAGCCAACTCGTCACAGTCC }\end{array}$ & 255 & 46 \\
\hline PTHrP & $\begin{array}{l}\text { Forward: GTCTCAGCCGCCGCCTCAA } \\
\text { Reverse: GGAAGAATCGTCGCCGTAAA }\end{array}$ & 93 & 47 \\
\hline VDR & $\begin{array}{l}\text { Forward: CCAGTTCGTGTGAATGATGG } \\
\text { Reverse: CCTTTTGGATGCTGTAACTG }\end{array}$ & 256 & - \\
\hline
\end{tabular}

${ }^{*}$ All primers were designed as described previously, except primer pairs for VDR and CREB-5, which were designed for the present study with Primer 3 software (v. 0.3.0; Whitehead Institute for Biomedical Research (http://frodo.wi.mit.edu/cgi-bin/primer3/primer3_www.cgi)). 

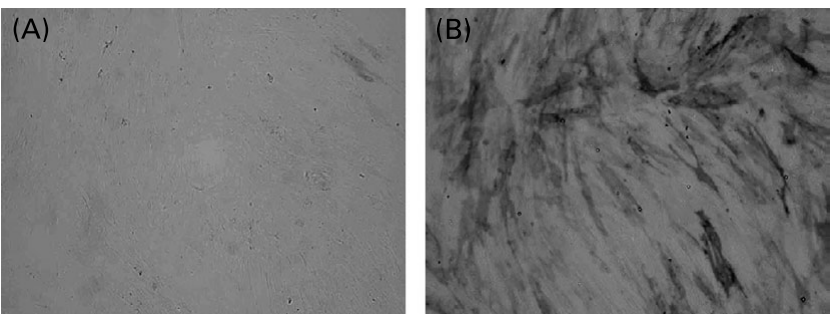

Fig. 1. Alkaline phosphatase (ALP) staining of undifferentiated human mesenchymal stem cells (hMSC) (A) and hMSC differentiated into osteoblasts (B). Cultures of undifferentiated cells showed no ALP staining, whereas differentiated cells showed strong staining for ALP.

\section{Microarray and data processing}

The Hum16-K cDNA microarrays were printed on glass slides in the Finnish DNA Microarray Center at Turku Centre for Biotechnology. The chips contain approximately 16000 annotated genes selected from the Finnish DNA Microarray Centre's Research Genetics clone library spotted in duplicate on a glass slide. The array design accession number is A-MEXP-557 (http://www.ebi.ac.uk/arrayexpress/). The expression profiles of osteoblasts differentiated from hMSC were compared after a $24 \mathrm{~h}$ treatment with $50 \mu \mathrm{M}$-IPP, VPP or LKP. Samples were labelled with FluoroLink Cy-3-dUTP and Cy-5-dUTP (Amersham Biosciences, Uppsala, Sweden) using $20 \mu \mathrm{g}$ of total RNA for direct labelling and hybrized using augmented reference design ${ }^{25}$. Discrete images for $\mathrm{Cy}$ 3 and Cy-5 dyes were obtained using a Scan Express laserscanning microscope (Packard BioSciences, Meriden, CT, USA) and gene transcript levels were determined from the fluorescence intensities of scanned data image files with the QuantArray Microarray Analysis software (Packard BioSciences). Gene expression profiles were analysed by Kensington Discovery Edition 2.0 software (Inforsense, Cambridge, MA, USA). Replicates were analysed by $t$ test to define normal versus changed gene expression within treatments. Results were considered significant at the $95 \%$ significance level $(P<0.05)$. At a $P$ value of 0.05 the fold difference in gene expression was 1.8 and it was used in control/treatment comparison to show up- and down-regulated genes. The cDNA microarray experiment is available at accession number E-MEXP-885 (http://www.ebi.ac.uk/arrayexpress/).

\section{Quantitative real-time PCR}

The cDNA microarray results were confirmed by quantitative real-time reverse transcription PCR for $\beta$-actin, BMP-2, BMP-5, caspase-8, CREB-5, PTHrP and VDR. The RNA preparations (two biological replicates) were used for cDNA synthesis. cDNA was synthesized from $1.5 \mu \mathrm{g}$ of total RNA by the method described earlier ${ }^{26}$. Each PCR amplification was performed in a qRT-PCR (Mx3000P; Stratagene, La Jolla, CA, USA) according to the manufacturer's instructions using Brilliant SYBR Green QPCR Master mix kit (Stratagene) and cDNA as templates in a $25 \mu \mathrm{l}$ reaction volume containing $200 \mathrm{~nm}$ of the gene-specific primer (Table 1). Fluorescence data were collected during annealing step and analysed with Mx3000P software. Amplification was obtained by denaturing at $95^{\circ} \mathrm{C}$ for $10 \mathrm{~min}$, followed by forty cycles of denaturing at $95^{\circ} \mathrm{C}$ for $30 \mathrm{~s}$, annealing at $58^{\circ} \mathrm{C}$ for $1 \mathrm{~min}$, and extension at $72^{\circ} \mathrm{C}$ for $30 \mathrm{~s}$. For dissociation measurement, the amplification cycle was followed by $1 \mathrm{~min}$ at $95^{\circ} \mathrm{C}$ and $30 \mathrm{~s}$ at $55^{\circ} \mathrm{C}$, after which the temperature was returned to $95^{\circ} \mathrm{C}$.

A dilution series of cDNA from human brain total RNA (BD, Biosciences, Clontech) was used as a calibration standard, and data were normalized by the amplification results of $\beta$-actin. All reactions were run in triplicate with five dilution concentrations, and the mean value was used to calculate the ratio of target gene/ $\beta$-actin expression in each sample. Using the ratio in an untreated sample as a standard (100), the relative ratio of the treated sample was presented as the relative expression level of the target gene.

\section{Statistical analysis}

Statistical analyses were performed with GraphPad Prism software version 3.03 (GraphPad Prism, San Diego, CA, USA) and SPSS version 13.0 (SPSS Inc., Chicago, IL, USA). Results are expressed as means and their standard errors of at least two independent experiments. Data were analysed using either Student's unpaired $t$ test or ANOVA and followed by Tukey's post hoc test. The microarray gene expression data for IPP-treated osteoblasts was analysed by principal component analysis to determine the main components affected. Results were considered significant at the $95 \%$ significance level $(P<0.05)$.

\section{Results \\ Cell proliferation}

The preliminary screening of the peptides with UMR-106 cell culture model revealed that all of the tripeptides studied increased cell proliferation as compared with the control cells (Fig. 2(A)). After a $24 \mathrm{~h}$ treatment, $50 \mu \mathrm{M}$-IPP increased hMSC proliferation (Fig. 2(B, C)). In a dose-response study with mature osteoblasts, IPP decreased proliferation at a concentration of $500 \mu \mathrm{M}$ (Fig. 2(D)). In a time-response study with $50 \mu \mathrm{M}$-IPP, no change was seen in osteoblast proliferation at 3, 24 or $48 \mathrm{~h}$ (Fig. 2(E)).

\section{Microarray}

Expression profiling was performed by cDNA microarray. Microarray data analysis revealed IPP to regulate more genes in osteoblasts than VPP or LKP. IPP up-regulated 270 genes and down-regulated 100 genes. The respective numbers for VPP were twenty-five and ten and for LKP they were sixteen and fourteen. IPP did not only regulate a larger number of genes than VPP or LKP, but IPP was also the only tripeptide to up-regulate osteogenic differentiation factors (Table 2). The principal component analysis included 245/270 upregulated genes and 47/100 down-regulated genes into the different components. The principal component analysis revealed $45 \%$ of the variation in the up-regulated genes from the IPP-treated osteoblasts could be addressed to the first principal component. The second principal component explained $25.3 \%$ and the third $22.6 \%$ of the variation. The first component (115 genes) contained had heavy positive loadings on differentiation-, receptor-, mitochondria-, apoptosis-, enzyme-, 


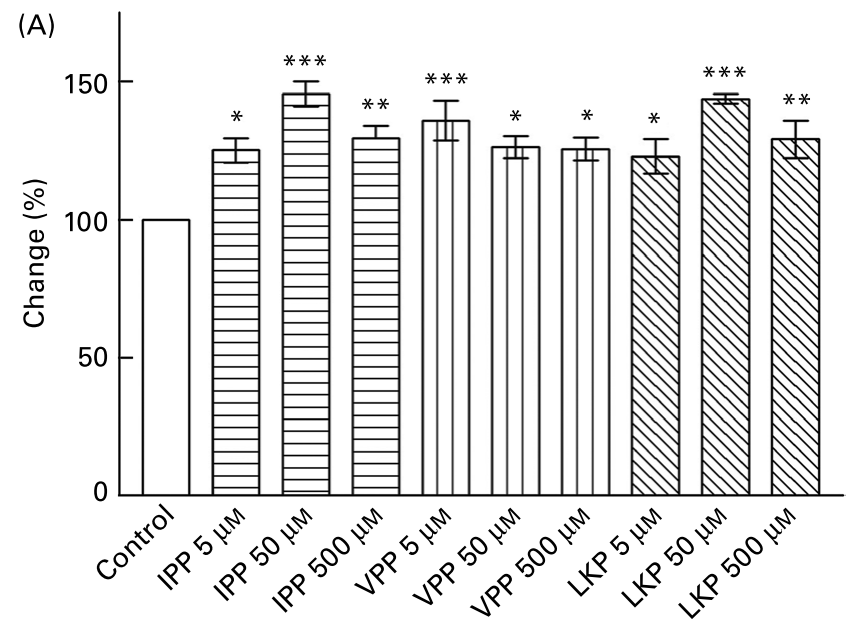

(B)

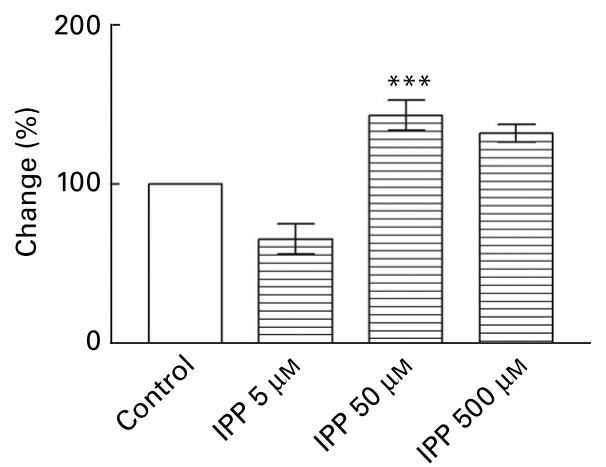

(D)

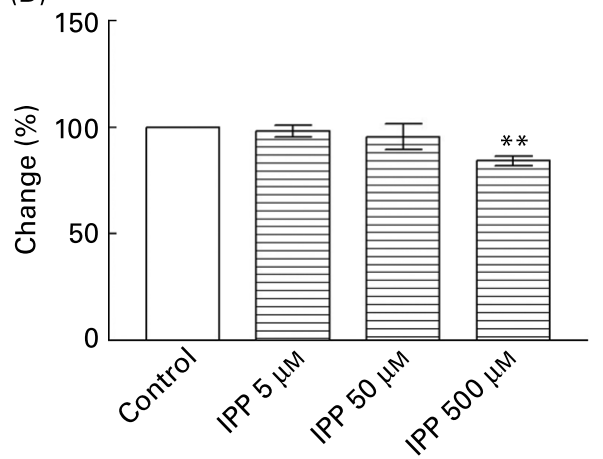

(C)

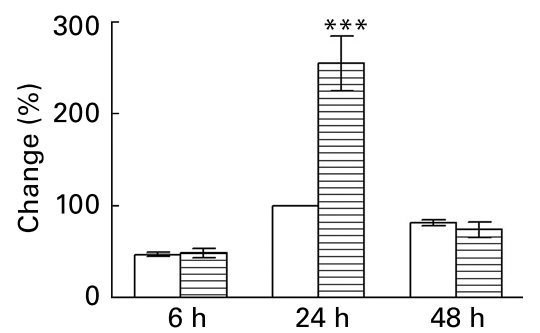

(E)

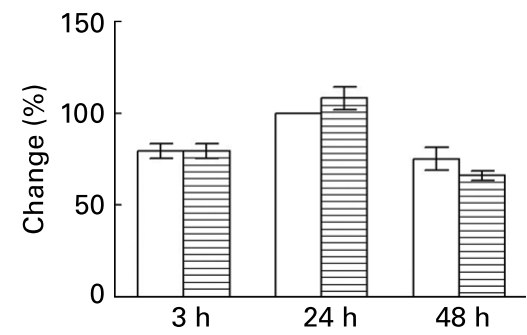

Fig. 2. Cell proliferation: results are shown as the relative amounts of 5-bromo-2'-deoxyuridine (BrdU) incorporation. The mean amount of BrdU incorporation in the control cells after $24 \mathrm{~h}$ treatment has been given the value 100 . Values are means with their standard errors depicted by vertical bars. (A), UMR-106 cell proliferation was increased by $24 \mathrm{~h}$ peptide treatment. Mean values were significantly different from those of the controls (ANOVA and Tukey's post hoc test): ${ }^{\star} P<0.05,{ }^{\star \star} P<0.01,{ }^{\star \star \star} P<0.001$. (B), Dose-response effect of isoleucine-proline-proline (IPP) on human mesenchymal stem cells (hMSC) after $24 \mathrm{~h}$ treatment showed $50 \mu \mathrm{M}$ increased cell proliferation. Mean values were significantly different from those of the controls (ANOVA and Tukey's post hoc test): ${ }^{* \star *} P<0.001$. (C), The time-response effect of $50 \mu \mathrm{M}$-IPP (目) was increased $\mathrm{hMSC}$ proliferation after $24 \mathrm{~h}$ treatment $(\square$, control). Mean values were significantly different from those of the controls (unpaired Student's $t$ test): ${ }^{* \star \star} P<0.001$. (D), Osteoblast proliferation was decreased with $500 \mu \mathrm{M}$-IPP $(24 \mathrm{~h})$. Mean values were significantly different from those of the controls (ANOVA and Tukey's post hoc test): ${ }^{\star \star} P<0.01$. (E), IPP (50 $\mu \mathrm{M}$; 目) had no effect on osteoblast proliferation at 3,24 or $48 \mathrm{~h}$ $(\square$, control). LKP, leucine-lysine-proline; VPP, valine-proline-proline.

signal transduction-, membrane architecure-, function- and transport-related genes. Thus we named it 'Up-regulated cell differentiation'. The second component (forty-seven genes) had heavy positive loadings on cell adhesion-, osteogenic differentiation-, and cell growth and proliferation-related genes. This component was named 'Up-regulated cell growth'. The third component (eighty-three genes) had heavy positive loadings on transcription-, splicing-, translation-, expressed sequence tag- and 'unknown functions'-related genes, hence it was named 'Up-regulated cell transcription'. Table 3 presents a set of interesting up-regulated genes with a high fold change. 
Table 2. Summary of the microarray analysis: number of up-regulated (Up) and down-regulated (Down) genes by isoleucine-proline-proline (IPP), valine-proline-proline (VPP) and leucine-lysine-proline (LKP) in osteoblasts differentiated from human mesenchymal stem cells and the average fold change

\begin{tabular}{|c|c|c|c|c|c|c|c|c|c|c|c|c|c|c|c|c|c|c|}
\hline \multirow[b]{2}{*}{ Functional group } & \multicolumn{6}{|c|}{ IPP } & \multicolumn{6}{|c|}{ VPP } & \multicolumn{6}{|c|}{ LKP } \\
\hline & Up & Average & SD & Down & Average & SD & Up & Average & SD & Down & Average & SD & Up & Average & SD & Down & Average & SD \\
\hline Adhesion, cytoskeleton & 13 & 3.2 & 0.73 & 8 & -2.5 & 0.24 & 2 & $1 \cdot 6$ & 0.07 & 1 & $-1 \cdot 2$ & 0.00 & 1 & $2 \cdot 0$ & 0.00 & & & \\
\hline Antiapoptosis & 3 & $2 \cdot 8$ & 0.31 & 1 & $-2 \cdot 6$ & 0.00 & & & & & & & 1 & $2 \cdot 0$ & 0.00 & & & \\
\hline Apoptosis & 5 & 3.2 & 0.87 & 3 & $-2 \cdot 3$ & 0.06 & 2 & 1.9 & 0.43 & & & & & & & & & \\
\hline Cell cycle, growth, proliferation & 25 & 2.9 & 0.63 & 4 & $-2 \cdot 2$ & 0.05 & 2 & $2 \cdot 1$ & 0.04 & 2 & -1.6 & 0.04 & & & & 2 & -1.9 & 0.12 \\
\hline Oncogenes & 4 & 3.0 & 0.98 & 3 & -2.5 & 0.15 & 1 & $1 \cdot 7$ & 0.00 & & & & & & & & & \\
\hline Suppressor genes & 1 & $2 \cdot 8$ & 0.00 & 2 & $-2 \cdot 4$ & 0.07 & & & & 1 & -3.9 & 0.00 & & & & 1 & $-2 \cdot 3$ & 0.00 \\
\hline Differentiation & 15 & $2 \cdot 8$ & 0.31 & 4 & $-2 \cdot 6$ & 0.54 & 2 & $2 \cdot 8$ & 0.04 & 2 & -1.5 & 0.01 & & & & 3 & $-2 \cdot 0$ & 0.44 \\
\hline Osteogenic factors & 7 & 3.0 & 0.60 & & & & & & & & & & & & & & & \\
\hline Enzymes, metabolism & 23 & $2 \cdot 7$ & 0.46 & 7 & -2.5 & 0.28 & 2 & 1.8 & 0.01 & & & & 3 & 3.4 & $2 \cdot 81$ & 1 & -1.9 & 0.00 \\
\hline EST and unknown functions & 46 & 2.9 & 0.54 & 11 & -2.6 & 0.44 & 5 & 1.9 & 0.57 & 2 & $-2 \cdot 0$ & 0.29 & 4 & 1.9 & 0.67 & 1 & $-2 \cdot 3$ & 0.00 \\
\hline $\begin{array}{l}\text { Extracellular matrix, cell } \\
\text { migration }\end{array}$ & 4 & $2 \cdot 9$ & 0.11 & 6 & -2.5 & 0.33 & & & & 1 & $-1 \cdot 7$ & 0.00 & & & & & & \\
\hline $\begin{array}{l}\text { Hormones, hormone- and } \\
\text { cytokine-related proteins }\end{array}$ & 4 & 2.9 & 0.47 & 1 & $-2 \cdot 2$ & 0.00 & & & & & & & & & & & & \\
\hline Immunosystem & 5 & 3.4 & 0.94 & 2 & $-3 \cdot 1$ & $1 \cdot 13$ & & & & & & & & & & & & \\
\hline $\begin{array}{l}\text { Membrane architecture, function, } \\
\text { transport }\end{array}$ & 27 & $2 \cdot 8$ & 0.46 & 13 & $-2 \cdot 4$ & 0.18 & 1 & $1 \cdot 6$ & 0.00 & & & & 1 & $4 \cdot 1$ & 0.00 & & & \\
\hline Mitochondria & 7 & $2 \cdot 8$ & 0.54 & 4 & -2.4 & 0.28 & & & & & & & & & & 1 & -1.8 & 0.00 \\
\hline Receptors and their regulators & 9 & $2 \cdot 8$ & 0.58 & 4 & $-2 \cdot 2$ & 0.19 & 3 & $1 \cdot 7$ & 0.17 & & & & & & & 1 & -4.9 & 0.00 \\
\hline Signal transduction & 29 & $2 \cdot 8$ & 0.52 & 8 & $-2 \cdot 6$ & 0.54 & 3 & $2 \cdot 1$ & 0.69 & 1 & -1.4 & 0.00 & 4 & $2 \cdot 0$ & 0.22 & 3 & $-3 \cdot 1$ & 2.44 \\
\hline Transcription, splicing, translation & 37 & 2.9 & 0.54 & 15 & $-2 \cdot 4$ & 0.34 & & & & & & & 2 & $1 \cdot 8$ & 0.10 & 1 & -1.5 & 0.00 \\
\hline Zing finger proteins & 6 & $2 \cdot 7$ & 0.53 & 4 & -2.5 & 0.8 & 2 & $1 \cdot 7$ & 0.05 & & & & & & & & & \\
\hline Total & 270 & 2.9 & 0.55 & 100 & -2.5 & 0.37 & 25 & 1.9 & 0.38 & 10 & -1.9 & 0.76 & 16 & $2 \cdot 3$ & 1.28 & 14 & $-2 \cdot 4$ & 1.32 \\
\hline
\end{tabular}

EST, expressed sequence tags. 
Table 3. Effect of isoleucine-proline-proline $(50 \mu \mathrm{M}, 24 \mathrm{~h})$ on microarray-analysed gene expression in human osteoblasts (a set of selected up-regulated genes divided into three principal component analysis categories)

\begin{tabular}{|c|c|c|}
\hline Principal component/Accession no. & Gene/protein & Fold change \\
\hline \multicolumn{3}{|l|}{ Up-regulated cell differentiation } \\
\hline \multicolumn{3}{|l|}{ Differentiation } \\
\hline AA011062 & Bone morphogenetic protein 2 & $2 \cdot 1$ \\
\hline AA779457 & Bone morphogenetic protein 5 & $2 \cdot 4$ \\
\hline \multicolumn{3}{|l|}{ Receptors and their regulators } \\
\hline R51015 & Thyroid-stimulating hormone receptor & $2 \cdot 7$ \\
\hline R43817 & Neuropeptide $\mathrm{Y}$ receptor $\mathrm{Y} 1$ & 3.9 \\
\hline \multicolumn{3}{|l|}{ Mitochondria } \\
\hline \multirow[t]{2}{*}{ AA176581 } & Myoglobin & $3 \cdot 7$ \\
\hline & $\beta$-Polypeptide cytochrome $b$-245 & $2 \cdot 2$ \\
\hline \multicolumn{3}{|c|}{ 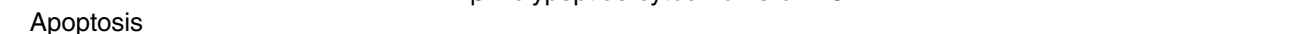 } \\
\hline AA620708 & Apoptosis regulator BCL-G & 1.9 \\
\hline R49650 & Fas apoptotic inhibitory molecule 2 & 1.8 \\
\hline \multicolumn{3}{|l|}{ Enzymes and metabolism } \\
\hline H87471 & Kynureninase (L-kynurenine hydrolase) & 3.0 \\
\hline N51496 & EF hand calcium binding protein 1 & $2 \cdot 5$ \\
\hline \multicolumn{3}{|l|}{ Signal transduction } \\
\hline \multirow[t]{2}{*}{ R22790 } & cAMP responsive element binding protein 5 & $2 \cdot 3$ \\
\hline & Guanine nucleotide binding protein ( $G$ protein) & $2 \cdot 3$ \\
\hline \multicolumn{3}{|c|}{ Membrane architecture, function and transport } \\
\hline & Laminin $\gamma-3$ & $2 \cdot 7$ \\
\hline AA621725 & Nucleoporin $43 \mathrm{kDa}$ & $2 \cdot 8$ \\
\hline \multicolumn{3}{|l|}{ Up-regulated cell growth } \\
\hline \multicolumn{3}{|l|}{ Cell cycle, growth and proliferation } \\
\hline Al538525 & Mitogen-activated protein kinase kinase kinase 1 & $3 \cdot 1$ \\
\hline AA402447 & Mitogen-activated protein kinase kinase kinase 4 & $2 \cdot 3$ \\
\hline \multicolumn{3}{|l|}{ Adhesion and cytoskeleton } \\
\hline Al652836 & CD96 antigen & 4.6 \\
\hline N30615 & Contactin 6 & 3.0 \\
\hline \multicolumn{3}{|l|}{ Osteogenic differentiation } \\
\hline N69672 & Glycosylphosphatidylinositol-specific phospholipase D1 & $4 \cdot 2$ \\
\hline $\mathrm{Al} 272878$ & Fibroblast growth factor 20 & 3.2 \\
\hline \multicolumn{3}{|l|}{ Up-regulated cell transcription } \\
\hline \multicolumn{3}{|l|}{ Transcription, splicing and translation } \\
\hline AA857407 & Transcription factor 20 (AR1) & $2 \cdot 3$ \\
\hline AA975221 & Glucocorticoid modulatory element binding protein 2 & 3.0 \\
\hline AA609862 & RNA binding protein with multiple splicing & 3.9 \\
\hline \multicolumn{3}{|l|}{ EST or unknown function } \\
\hline AA608709 & Vasculin & 3.2 \\
\hline AA620709 & Hypothetical protein KIAA1434 & $4 \cdot 1$ \\
\hline AA448002 & CD209 antigen-like & $2 \cdot 3$ \\
\hline
\end{tabular}

EST, expressed sequence tags.

Principal component analysis on the down-regulated genes in IPP-treated cells showed $73.5 \%$ of the variation to be addressed to the first principal component (twenty genes) and the rest of the variation $(26.5 \%)$ could be addressed to the second component (twenty-seven genes). The first component had heavy positive loadings on cell differentiation-, apoptosis-, enzyme- and cell migration-related genes, hence we named it 'Down-regulated cell differentiation'. The second component captured the variance of cell cycle-, growth-, proliferation-, adhesion- and transcription related genes, hence we named it 'Down-regulated cell growth'. Table 4 presents a set of selected down-regulated genes divided into principal components.

\section{Quantitative real-time PCR}

A set of IPP-regulated genes was further analysed by qRT-PCR. Microarray analysis had revealed IPP-treated osteoblasts to express more differentiation genes (BMP-2, BMP-5), transcription factor genes (CREB-5) and hormone-related genes (PTHrP) than control cells. Apoptosis-related caspase- 8 and vitamin $\mathrm{D}$ receptor gene expression was decreased due to IPP treatment. The qRT-PCR results for these genes were in accordance with the microarray analysis and showed IPP to increase CREB-5, BMP-5 and PTHrP expression, whereas VDR and caspase-8 expression was decreased (Fig. 3). The effect of IPP on BMP-2 was not statistically significant.

\section{Discussion}

To our knowledge, the present study is the first to describe bioactive peptide IPP, VPP and LKP effects on osteoblast gene expression. IPP regulated more genes in hMSC-differentiated osteoblasts than VPP or LKP. The up-regulated genes could be categorized into three principal components: upregulated cell differentiation genes, up-regulated cell growth genes and up-regulated cell transcription genes. The upregulation of these genes indicates IPP enhancing osteoblast 
Table 4. Effect of isoleucine-proline-proline $(50 \mu \mathrm{M}, 24 \mathrm{~h})$ on microarray-analysed gene expression in human osteoblasts (a set of selected down-regulated genes divided into two principal component analysis categories)

\begin{tabular}{llr}
\hline $\begin{array}{l}\text { Principal component/Accession no. } \\
\text { Down-regulated cell differentiation } \\
\text { Differentiation } \\
\text { AA085749 }\end{array}$ & \multicolumn{1}{c}{ Gene/protein } & Fold change \\
Extracellular matrix and cell migration & ATP binding protein associated with cell differentiation & $-2 \cdot 1$ \\
& Protein tyrosine phosphatase receptor type & $-2 \cdot 2$ \\
Enzymes and metabolism & Collagen type II & $-2 \cdot 2$ \\
H53275 & Fibrinogen $\gamma$-polypeptide & $-2 \cdot 9$ \\
Apoptosis & Histamine N-methyltransferase & $-2 \cdot 9$ \\
& Glutamate-cysteine ligase modifier subunit & $-2 \cdot 5$ \\
Down-regulated cell growth & Caspase-8 & $-1 \cdot 9$ \\
Cell cycle, growth and proliferation & Protocadherin $\gamma$-subfamily C & $-2 \cdot 3$ \\
N47966 & & $-2 \cdot 2$ \\
Adhesion and cytoskeleton & Cell cycle progression 8 protein & $-2 \cdot 1$ \\
& Fanconi anaemia complementation group L & $-2 \cdot 8$ \\
Transcription, splicing and translation & Non-voltage-gated 1 $\alpha$ sodium channel & $-2 \cdot 6$ \\
N57921 & Tubulin $\gamma$-2 & $-2 \cdot 3$ \\
\hline
\end{tabular}

proliferation and differentiation. The present results also show IPP increasing UMR-106 and hMSC proliferation, but not the proliferation of mature osteoblasts. A previous study by Amedee et $a .^{27}$ showed mature osteoblast proliferation becoming limited as the state of differentiation increased, hence the present result is in line with their study. Biomaterial studies conducted with Arg-Gly-Asp-containing peptide

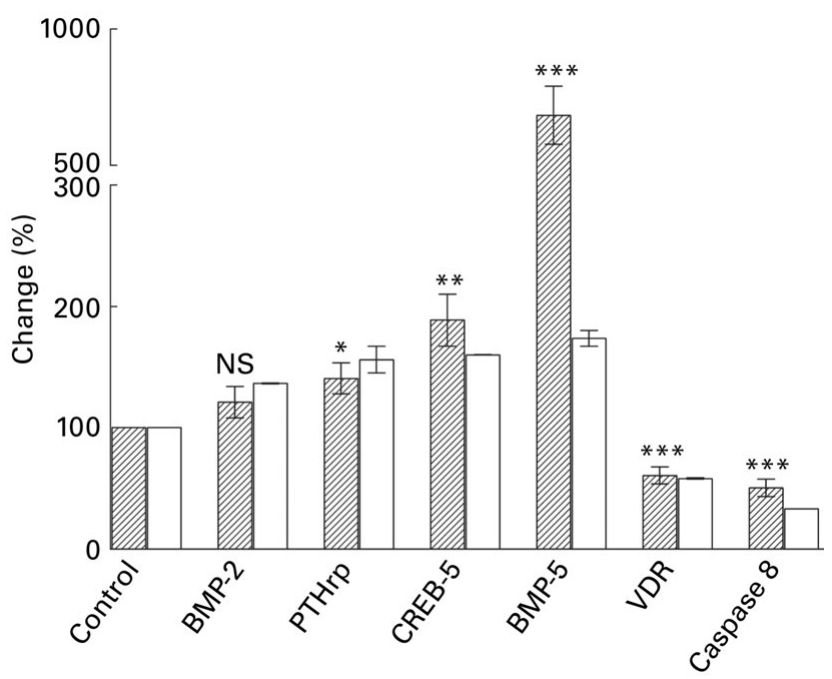

Fig. 3. The gene expression of isoleucine-proline-proline-treated osteoblasts analysed by a cDNA microarray method $(\square)$ and quantitative real-time PCR (qRT-PCR; $\square$ ). At least 1.8 -fold difference was used in control $v$. treatment comparison in microarray data, and the ratio in the untreated sample was used as a control (100). qRT-PCR results were normalized by amplification of the result of $\beta$-actin, and the untreated sample has been given the value 100. Values are means, with their standard errors depicted by vertical bars, of triplicate determinations, where all amplified genes have their own controls. Mean values were significantly different from those of the controls (unpaired Student's $t$ test): ${ }^{\star} P<0.05$, ${ }^{\star \star} P<0.01,{ }^{\star \star \star} P<0.001$. sequence also show increased primary calvarial osteoblast cell proliferation in response to the peptide ${ }^{28,29}$.

In the present study $24 \mathrm{~h}$ treatment with IPP increased UMR-106 and hMSC proliferation and up-regulated PTHrP and CREB-5 genes. Parathyroid hormone (PTH) exerts anabolic and catabolic effects in vivo on bone ${ }^{30}$. In vitro studies on osteoblasts have shown continuous treatment with very low concentration of PTH stimulates UMR-106-01 and primary osteoblast proliferation ${ }^{30,31}$. PTHrP is a polypeptide hormone sharing a common sequence with PTH. Both hormones can function with the PTH/PTHrP receptor ${ }^{32}$. PTHrP produced by osteoblasts is thought to function locally. Within the skeletal microenvironment, PTHrP propels pluripotential bone marrow stromal cells towards the osteogenic lineage and also exerts antiapoptotic effects ${ }^{33}$. The ability of PTH to drive changes in gene expression is dependent upon activation of transcription factors such as the cAMP response element binding protein $(\mathrm{CREB})^{34}$. In response to PTH, CREB is phosphorylated and in turn activates transcription. The increased proliferation in IPP-treated hMSC could be due to increased PTHrP and CREB. Because cell proliferation and maturation are sequential processes, increased numbers of pluripotent cells and their augmented maturation into osteoblasts could increase the total number of osteoblasts.

Osteoblast differentiation can be divided into commitment of undifferentiated mesenchymal cells to osteoblast progenitors and their maturation into osteoblasts ${ }^{35}$. Bone morphogenetic proteins (BMP) are multifunctional regulators of cells of the osteoblastic lineage. In osteoblasts BMP regulate growth, differentiation and apoptosis. A fundamental function of BMP is to induce the differentiation of mesenchymal cells towards cells of the osteoblastic lineage ${ }^{36}$. As a result, the pool of mature osteoblastic cells increases ${ }^{36}$. The BMP family can be divided into several subgroups based on the BMP gene sequence identity. In this family tree, BMP-5 and 
-6 belong to the same subgroup. BMP-6 induces osteoblast differentiation and maturation ${ }^{35}$ and BMP-5 has similar osteoinductive properties ${ }^{37}$. BMP also play a role in fracture healing ${ }^{36}$, especially BMP-5, as one characteristic of BMP-5 null mice is impaired fracture repair. The ability of IPP to induce BMP-5 production can increase osteoblast differentiation and augment fracture repair, a feature associated with a protein-rich $\operatorname{diet}^{5-7}$. Here, the microarray results showed that IPP up-regulated BMP-2. However, qRT-PCR results revealed no statistical difference in BMP-2 expression between control and IPP-treated cells. As BMP-2 functions early in the cell differentiation pathway ${ }^{36}$, an analysis at an earlier stage might have produced a more significant effect.

Vitamin D receptor (VDR) attenuates osteoblast differentiation in vitro ${ }^{38}$. Osteoblasts lacking VDR have enhanced differentiation, as shown by increased alkaline phosphatase activity and increased formation of mineralized matrix. An in vivo experiment with VDR knock-out mice revealed increased bone volume and density compared with wild-type mice $^{39}$. The present study showed that IPP decreased VDR, which could lead to an increase in differentiation and bone formation. A previous in vitro study on mouse bone marrow-derived osteoblast precursors has shown IPP and VPP activating osteoblast bone formation ${ }^{40}$.

The down-regulated genes in IPP-treated osteoblasts were divided into two principal components: cell differentiation genes and cell growth-related genes. Apoptosis-related genes were located in the 'Down-regulated cell differentiation' component. Apoptosis is the major cause of osteoblast cell death. Jilka et $a{ }^{41}{ }^{41}$ have shown osteoblast apoptosis to be under the regulatory control of factors produced in the bone microenvironment. Caspases are essential apoptosis effectors, exerting their effects in a cascade involving receptor- and mitochondria-dependent pathways ${ }^{42}$. Caspase- 8 is a receptor-mediated caspase which in turn activates caspase-3, the true executioner leading to cell apoptosis. In the present study, caspase- 8 was down-regulated and PTHrP up-regulated, suggesting that IPP exerts antiapoptotic effects on osteoblasts. Alterations in the timing and extent of osteoblast apoptosis could have a significant impact on the rate of bone formation ${ }^{41}$. Furthermore, the number of osteoblasts increases if cell proliferation and differentiation is increased and cell apoptosis is decreased.

The present results at the cellular and mRNA levels show tripeptide IPP increasing cell proliferation. Genes associated with cell differentiation were up-regulated and apoptosis inducers were down-regulated. The present findings indicate that IPP enhances gene expression in a way that would increase the differentiation of hMSC into osteoblasts and prolong their viability. Agents that increase the number and function of osteoblasts improve bone mass and structure, thereby decreasing the risk of fracture. Bioactive peptides, such as IPP, might well contribute to the positive effects dietary protein has on bone mineral mass and decreased fracture risk.

\section{Acknowledgements}

We are grateful to the Turku Centre for Biotechnology, University of Turku and Åbo Akademi University, Finland, for the cDNA microarray hybridizations. This work was supported by a grant from the Finnish National Agency of
Technology. M. H. and M. P. had equal contribution to conducting the study and writing the paper. M. A. and C. L.-A. supervised the study and contributed to revision of the manuscript. None of the authors have any conflict of interest.

\section{References}

1. Hannan MT, Tucker KL, Dawson-Huges B, Cupples LA, Felson DT \& Kiel DP (2000) Effect of dietary protein on bone loss in elderly men and women: The Framingham Osteoporosis Study. $J$ Bone Miner Res 15, 2504-2512.

2. Dawson-Huges B \& Harris SS (2002) Calcium intake influences the association of protein intake with rates of bone loss in elderly men and women. Am J Clin Nutr 75, 773-779.

3. Kerstetter JE, O'Brien KO \& Insogna KL (2003) Low protein intake: the impact on calcium and bone homeostasis in humans. $J$ Nutr 133, 855S-861S.

4. Wengreen HJ, Munger RG, West NA, Cutler DR, Corcoran CD, Zhang J \& Sassano NE (2004) Dietary protein intake and risk of osteoporotic hip fracture in elderly residents of Utah. $J$ Bone Miner Res 19, 537-545.

5. Bastow MD, Rawlings J \& Allison SP (1983) Benefits of supplementary tube feeding after fracture neck of femur. $\mathrm{Br}$ Med $J$ 287, 1589-1592.

6. Delmi M, Rapin C-H, Bengoa JM, Delmas PD, Vasey H \& Bonjour J-P (1990) Dietary supplementation in elderly patients with fractured neck of the femur. Lancet 335, 1013-1016.

7. Rizzoli R \& Bonjour J-P (2004) Dietary protein and bone health. J Bone Miner Res 19, 527-531.

8. Oxlund H, Barckman M, Ørtoft G \& Andreassen TT (1995) Reduced concentrations of collagen cross-links are associated with reduced strength of bone. Bone 17, 365S-371S.

9. Heaney RP (2002) Protein and calcium: antagonists or synergists? Am J Clin Nutr 75, 609-610.

10. Kerstetter JE, O’Brien KO, Caseria DM, Wall DE \& Insogna KL (2005) The impact of dietary protein on calcium absorption and kinetic measures of bone turnover in women. $J$ Clin Endocrinol Metab 90, 26-31.

11. Thissen JP, Ketelslegers JM \& Underwood LE (1994) Nutritional regulation of the insulin-like growth factors. Endocr Rev 15, 80-101.

12. Rutherfurd-Markwick KJ \& Moughan PJ (2005) Bioactive peptides derived from food. J AOAC Int 88, 955-966.

13. Hartmann R \& Meisel H (2007) Food-derived peptides with biological activity: from research to food applications. Curr Opin Biotechnol 18, 1-7.

14. Fujita H \& Yoshikawa M (1999) LKPNM: a prodrug-type ACEinhibitory peptide derived from fish protein. Immunopharmacology 44, 123-127.

15. Shimizu M (2004) Food-derived peptides and intestinal functions. Biofactors 21, 43-47.

16. Satake M, Enjoh M, Nakamura Y, Takano T, Kawamura Y, Arai S \& Shimizu M (2002) Transepithelial transport of the bioactive tripeptide, Val-Pro-Pro, in human intestinal Caco-2 cell monolayers. Biosci Biotechnol Biochem 66, 378-384.

17. Froetschel MA, Azain MJ, Edwards GL, Barb CR \& Amos HE (2001) Opioid and cholecystokinin antagonists alleviate gastric inhibition of food intake by premeal loads of casein in mealfed rats. J Nutr 131, 3270-3276.

18. Aimutis WR (2004) Bioactive properties of milk proteins with particular focus on anticariogenesis. J Nutr 134, 989S-995S.

19. FizGerald RJ, Murray BA \& Walsh DJ (2004) Hypotensive peptides from milk proteins. J Nutr 134, 980S-988S.

20. Curtis JM, Dennis D, Waddell DS, MacGillivray T \& Ewart HS (2002) Determination of angiotensin-converting enzyme inhibi- 
tory peptide Leu-Lys-Pro-Asn-Met (LKPNM) in bonito muscle hydrolysates by LC-MS/MS. J Agric Food Chem 50, 3919-3925.

21. Narva M, Collin M, Lamberg-Allardt C, Kärkkäinen M, Poussa T, Vapaatalo H \& Korpela R (2004) Effects of long-term intervention with Lactobacillus helveticus-fermented milk on bone mineral density and bone mineral content in growing rats. Ann Nutr Metab 8, 228-234.

22. Narva M, Nevala R, Poussa T \& Korpela R (2004) The effect of Lactobacillus helveticus fermented milk on acute changes in calcium metabolism in postmenopausal women. Eur J Nutr 43, 61-68.

23. Stanford CM, Jacobson PA, Eanes EA, Lembke LA \& Midura RJ (1995) Rapidly forming apatic mineral in an osteoblastic cell line (UMR 106-01). J Biol Chem 270, 9420-9428.

24. Bodine PV, Trailsmith M \& Komm BS (1996) Development and characterization of a conditionally transformed adult human osteoblastic cell line. J Bone Miner Res 11, 806-819.

25. Kerr MK \& Churchill GA (2001) Experimental design for gene expression microarrays. Biostatistics 2, 183-201.

26. Ahlström M, Pekkinen M, Huttunen $M$ \& Lamberg-Allardt $C$ (2004) Dexamethasone down-regulates cAMP-phosphodiesterase in human osteosarcoma cells. Biochem Pharmacol 69, $267-275$

27. Amedee J, Bareille R, Rouais F, Cunningham N, Reddi H \& Harmand M (1994) Osteogenin (bone morphogenetic protein 3) inhibits proliferation and stimulates differentiation of osteoprogenitors in human bone marrow. Differentiation 58, $157-164$

28. Huag H, Zhao Y, Liu Z, Zhang Y, Zhang H, Fu T \& Ma X (2003) Enhanced osteoblast functions on RGD immobilized surface. J Oral Implantol 29, 73-79.

29. Benoit DSW \& Anseth KS (2005) The effect on osteoblast function of colocalized RGD and PHSRN epitopes on PEG surfaces. Biomaterials 26, 5209-5220.

30. Dempster DW, Cosman F, Parisien M, Shen V \& Lindsay R (1993) Anabolic actions of parathyroid hormone on bone. Endocr Rev 14, 690-709.

31. Swarthout JT, Dogget TA, Lemker JL \& Partridge NC (2001) Stimulation of extracellular signal-regulated kinases and proliferation in rat osteoblastic cells by parathyroid hormone in protein kinase C-dependent. J Biol Chem 276, 7586-7592.

32. Walsh CA, Bowler WB, Bilbe G, Fraser WD \& Gallagher JA (1997) Effects of PTHrP gene expression in human osteoblasts: up-regulation with the kinetics of an immediate early gene. Biochem Biophys Res Commun 239, 155-159.

33. Karaplis AC \& Goltzman D (2000) PTH and THrP effects on the skeleton. Rev Endocr Metab Disord 1, 331-341.

34. Swarthout JT, D'Alonzo RC, Selvamurugan N \& Partridge N (2002) Parathyroid hormone-dependent signalling pathways regulating genes in bone cells. Gene 282, 1-17.
35. Ebisawa T, Tada K, Kitajima I, Tojo K, Sampath TK, Kawabata M, Miyazono K \& Imamura T (1999) Characterization of bone morphogenetic protein-6 signalling pathways in osteoblast differentiation. J Cell Sci 112, 3519-3527.

36. Canalis E, Economides AN \& Gazzerro E (2003) Bone morphogenetic proteins, their antagonists, and the skeleton. Endocr Rev 24, 218-235.

37. Wozney JM (2002) Overview of bone morphogenetic proteins. Spine 27, S2-S8.

38. Sooy K, Sabbagh Y \& Demay MB (2005) Osteoblasts lacking the vitamin D receptor display enhanced osteogenic potential in vitro. $J$ Cell Biochem 94, 81-87.

39. Tanaka H \& Seino Y (2004) Direct action of 1,25-dihydroxyvitamin D on bone: VDRKO bone shows excessive bone formation in normal mineral condition. J Steroid Biochem Mol Biol 89/90, 343-345.

40. Narva M, Halleen J, Väänänen K \& Korpela R (2004) Effects of Lactobacillus helveticus fermented milk on bone cells in vitro. Life Sci 75, 1727-1734.

41. Jilka RL, Weinstein RS, Bellido T, Parfitt AM \& Manolagas SC (1998) Osteoblast programmed cell death (apoptosis): modulation by growth factors and cytokines. J Bone Miner Res 13, 793-802.

42. Morales O, Samuelsson MKR, Lindgren U \& Haldosén L

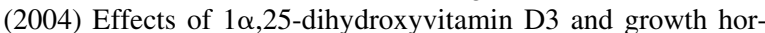
mone on apoptosis and proliferation in UMR 106 osteoblastlike cells. Endocrinology 145, 87-94.

43. Wordinger RJ, Agarwal R, Talati M, Fuller J, Lambert W \& Clark AF (2002) Expression of bone morphogenetic proteins (BMP), BMP receptors, and BMP associated proteins in human trabecular meshwork and optic nerve head cells and tissues. Mol Vis 8, 241-250.

44. Emmanuele L, Ortmann J, Doerflinger T, Traupe T \& Barton M (2003) Lovastin stimulates human vascular smooth muscle cell expression of bone morphogenetic protein-2, a potent inhibitor of low-density lipoprotein-stimulated cell growth. Biochem Biophys Res Commun 320, 67-72.

45. Gomes AC, Jönsson G, Mjörnheim S, Olsson T, Hillert J \& Grandien A (2003) Upregulation of the apoptosis regulators cFLIP, CD95, and CD95 ligand in peripheral blood mononuclear cells in relapsing-remitting multiple sclerosis. $\mathrm{J} \mathrm{Neu}$ roimmunol 135, 126-134.

46. Kuliwaba JS, Findlay DM, Atkins GJ, Forwood MR \& Fazzalari NL (2000) Enhanced expression of osteocalcin mRNA in human osteoarthritic trabecular bone of the proximal femur is associated with decreased expression of interleukin- 6 and interleukin-11 mRNA. J Bone Miner Res 15, 332-341.

47. Richard V, Luchin A, Brena RM, Plass C \& Rosol TJ (2003) Quantitative evaluation of alternative promoter usage and $3^{\prime}$ splice variants for parathyroid hormone-related protein by real-time reverse transcription-PCR. Clin Chem 49, 1398-1402. 